\section{On changing water into wine}

SIR - In advocating the memetic basis of religion, M. Vaneechoutte ${ }^{1}$ has overlooked or deliberately ignored the written record upon which Christianity is based. Jesus Christ was a real man who claimed to be the son of God and whose teachings were heard and whose words and actions were recorded for posterity. Neither Jesus nor his contentious teachings were conjured up by the human intellect in order to endow an individual with certainty about his or her fate (excepting perhaps the fate of persecution suffered by the early Christians). On the contrary, Jesus taught that no one has ever seen God ${ }^{2}$, and he left mankind with no reassurances about its fate $^{3}$. Hence Christianity as a religion is far from being memetically based.

Part of the basis of my religious belief stems from a physicochemical change that occurred nearly 2,000 years ago and that, to my knowledge, has not been repeated since. A wedding party at which Jesus was present ran out of wine, and Jesus's mother urged him to do something about it. Somewhat reluctantly, he told the servants to fill some stone water jars with water. Upon tasting it, the bridegroom was surprised that such good wine had been held back to the last ${ }^{4}$. I imagine that for people of that nonscientific age, the changing of water into wine must have been an impressive feat of 'magic', which must be why the event was recorded. Changing water into wine may seem insignificant in comparison to the subsequent deeds ascribed to Jesus in the New Testament, but all the physicists and chemists in today's world together could not begin to generate ethanol, a carbon-based compound, from hydrogen and oxygen atoms. When it is considered that the 'religion' of science holds that principles of physics and chemistry govern biological systems, it follows that anyone capable of transforming 'inanimate' matter would probably also be able to walk on water or repair matter within the human body, as Jesus is said to have done.

Being a follower of Christ comes down to a question of faith, not memetics. Just as I have faith in science as being the pursuit of truth, thanks to the written record in the Bible $I$ also have faith in Jesus, a person who taught that the pursuit of truth is worthwhile and that we are God's creation, not He ours.

\section{R. A. Savidge}

University of New Brunswick,

Fredericton, New Brunswick, E3B 6C2, Canada

SIR - Vaneechoutte ${ }^{1}$ postulates a memetic basis for religion. Unfortunately his hypothesis is based on a false premise. $\mathrm{He}$ asserts that "the essence of religion remains the influencing of the future: the major reason for behaving according to the rules is that one can propitiate the deity by doing so". This is a clear confusion between the objectives of science and religion.

When I stand in a pulpit on a Sunday, I preach the major Methodist doctrine that we are saved by grace through faith alone. Simply, this doctrine means that no action(s) of our own - whether good or bad - can influence God's actions towards us. God chooses to bless us because it is his nature to do so. However, when I work as a research material scientist throughout the week I obey the rules because I can propitiate my employer and my scientific peers by doing so.

Vaneechoutte argues that religion is an emergent characteristic which is a meme which reduces fear, uncertainty and depression. It may be an emergent characteristic but its challenges often increase fear, uncertainty and depression. Indeed, the practice of Christianity is almost certain to increase the need to cope with these effects.

For example, the fundamental principle of the Christian religion is the commandment of Christ that his followers should love their neighbours as themselves. Simply, this means sharing the pain, risks and problems of neighbours. When pressed to define a neighbour, Christ explained that they are those one most dislikes. He then illustrated this by the unnecessary, expensive and risky, compassionate care of a Samaritan for a Jew (that is, religious and racial opponents) and called for extra service to Romans (hated representatives of the occupying power).

Vaneechoutte recognizes that his hypothesis cannot be equated with Buddhism, so he asserts that Buddhism is "generally not considered a religion". It is true that it is not necessary to believe in a deity to practise Buddhism, so some people have attempted to categorize it as a philosophy and not a religion. However, most of its followers and most others consider Buddhism to be a religion that may be practised by deists and atheists. Indeed, many Buddhists are monks whose only livelihood is the support of other Buddhists. Vaneechoutte has confused theism and religion in his attempt to construct a mechanistic explanation of the human desire for religion.

Perhaps Nature should obtain peerreview of theologians before it again publishes a piece about religion?

\section{Richard S. Courtney}

31 Rivelands Road, Swindon Village,

Cheltenham, Glos GL51 9RF, UK

1. Vaneechoutte. M. Nature 365, 290 (1993)

2. Bible (John 6:46)

3. Bible (Mark 13:19; John 5:28-39).

4. Bible (John 2:1-11)

\section{Tools, not laws}

SIR - Andrew Ehrenberg's article "Even the social sciences have laws" (Nature $\mathbf{3 6 5}$, 385 ; 1993) may confirm the prejudices of many natural scientists against the social sciences. Ehrenberg says that major brands have more loyal customers than minor brands, and explains this by reference to a "law" called double jeopardy (DJ): those who only know the major brand buy it every time, as they do not know about equally good alternatives. That makes them more loyal than the customers of minor brands, who split their purchases between the two brands.

If DJ is a law, then it is also a law that twice two makes four. A parallel, in classical ("if $p$, then q") terms would be "if a bachelor, then unmarried". DJ is nothing but a logical implication of the assumption stated. A is a well-known brand, B is less well known but "equally good". It must be assumed that all who know B also know A.

It is implied in this information that A's customers will be more loyal than B's. Those who buy A do not know about B, whereas those who sometimes buy B by definition buy $\mathrm{A}$ as often. The only way in which we can confirm that the two brands are "equally good" is by letting a sample of the customers familiar with both make the choice in the supermarket.

If we consider DJ a falsifiable hypothesis, embodying a statement about the real world, and go out there to test it, it can only be confirmed. If we find a bachelor who is married, it does not falsify the "law" stated above; it is simply that he is not a bachelor. Likewise, if we find cases that seem to falsify DJ, the simplest explanation would be that the two brands are not, after all, "equally good", or that A-customers have other preferences than B-customers, which they were not supposed to have.

I do not know if there are social "laws". Those proposed have proved valid only if supplemented by an infinite number of conditioned clauses such as: "Valid only if not known by the population under investigation". Tireless attempts to provide nomothetic generalizations have given us much idiographic knowledge, but not the kind of reliable, stable and universally valid information about society that Boyle-Mariotte's law gives us about gases. DJ is not a law, but a tool that Ehrenberg and his colleagues can apply to the task of mapping empirical buying behaviour.

\section{Ottar Brox}

Norwegian Institute of Urban and Regional Research,

Oslo, Norway

Letters submitted for Correspondence should be typed, double-spaced, on one side of the paper only. 